\title{
Evidence that $\beta$-endorphin is synthesized in cells in the nicleus tractus solitarius: detection of POMC mRNA
}

\author{
David M. Bronstein, Martin K.-H. Schafer *, Stanley J. Watson and Huda Akil \\ Mental Health Research Institute, Unitersity of Michigan, Ann Arbor, MI 48109-0720 (USA)
}

(Accepted 10 March 1992)

Key words: $\beta$-Endorphin; Nucleus tractus solitarius; Pro-opiomelanocortin mRNA

\begin{abstract}
Evidence from a number of sources indicates that the major site of pro-opiomelanocortin (POMC)-producing cells in the CNS is the arcuate nucleus of the hypothalamus. Using immunocytochemical techniques, a second, smaller group of POMC cells has been detected in the nucleus tractus solitarius (NTS) area of the caudal medulla. However, POMC mRNA has never been reported in the NTS even though it has been found in other extrahypothalamic brain regions. Thus, there is some uncertainty as to whether POMC peptides are actually synthesized de novo in the NTS. In the present study, we used biochemical and anatomical techniques to examine whether POMC mRNA is localized in the NTS. Using in situ hybridization, cells containing POMC mRNA were found in the caudal portion of the NTS. The nucleic acid distribution correlated well with the anatomical distribution of $16 \mathrm{k}$ POMC peptide immunoreactivity as determined by immunocytochemistry. Northern analysis revealed that the apparent size of POMC mRNA in the NTS was similar to that found in the arcuate nucleus or the pituitary gland. Results of RNase protection assays using a POMC riboprobe complementary to the 5' end of exon 3 suggested that POMC mRNA in the NTS and arcuate nucleus are identical in this region of the message at least. We also calculated POMC peptide product to mRNA ratios in different tissues and found that NTS cells appear to produce less peptide per mRNA molecule than those in the arcuate nucleus or pituitary gland. Taken together, these data provide the strongest evidence to date that POMC is synthesized de novo in the NTS and offer support for a role for POMC.derived opioid and non-opioid peptides in atutonomic functions in the cuudal medulla.
\end{abstract}

\section{INTRODUCTION}

The potent opioid peptide $\beta$-endorphin $(\beta E)$ is derived from the precursor protein pro-opiomelanocortin (POMC). While there is abundant evidence that $\beta E$ may be a physiologically important peptide transmitter involved in diverse behaviors such as stress, pain, feeding, and autonomic responses (for review, see refs. 2 and 13), it has been difficult to define specific POMC pathways and to associate them with particular functions. Part of this difficulty relates to confusion about the precise localization of POMC somata and the anatomical distribution of their axonal projections. The major POMC cell group is found in the arcuate region of the mediobasal hypothalamus $3,4,14,26,29,36-3 k$. Axonal fibers from this cell group project to a number of brain areas including the septum, amygdala, various hypothalamic and thalamic nuclei and the midbrain. The discovery that POMC mRNA was also found in the arcuate nucleus "1" suggested that these cells intrinsically synthesized POMC peptides (as opposed, for example, to taking them up from the extracellular space). This hypothesis was confirmed by two sets of data: first, Liotta et al. demonstrated by pulse labelling techniques that cells in the arcuate could synthesize and process POMC peptides de novo; and second, using immunocytochemical (ICC) and in situ hybridization (ISH) techniques, cells in the arcuate were shown to contain both POMC mRNA and peptide product ".

At the present time, it is not clear whether other brain sites also contain cells which synthesize POMC peptide products de novo. Using ICC, several groups reported the existence of a second cluster of POMC cells in the nucleus tractus solitarius (NTS) area of the

Correspondence: D.M. Bronstein. Present address: LMIN, NIEHS, NIH, P.O. Box 12233, Mail Drop 14-06, Research Triangle Park. NC 27709. USA.

* Present address: Anatomisches Institut, Johannes Gutenberg Universitat, Saarstrasse 21, D-6500, Mainz, Germany. 
caudal medulla ${ }^{16.17 .33}$. It should be noted that, largely because of the small number of cells involved. this cell group was relatively difficult to find. It was not possible to detect POMC immunoreactivity in cell bodies in the NTS without prior treatment with large doses of colchicine (which inhibits peptide transport from the cell body down the axon). Recent findings ${ }^{7.18}$, indicating that neuropeptide mRNA expression can be induced by colchicine, raised the possibility that POMC may not be expressed in the NTS under normal conditions. This possibility gains strength when one considers that POMC message has, to date, never been found in the NTS despite the fact that it has been detected in a number of extrahypothalamic brain regions including the amygdala, cerebral cortex, midbrain and cerebellum ${ }^{(10.3)}$. Paradoxically, these brain regions do not contain POMC-containing cell bodies, as determined by ICC. Thus, there is some uncertainty as to whether biosynthesis of POMC peptides actually occurs in the NTS. To address this question, we employed three different techniques (in situ hybridization histochemistry, Northern analysis, and RNase protection) to examine whether POMC $m$ RNA could be detected in the brainstem. In addition, concentrations of $\beta E$-immunoreactive ( $\beta$ E-ir) peptides in the pituitary and different brain regions were measured in an attempt to compare the relative expression of POMC message and peptide.

\section{MATERIALS AND METHODS}

\section{Nuclitic acid amulyses}

Rudiolubelled POMC eRNA probe. POMC aDNA corresponding is the last 35 buses of intron B and the first 395 bases of exon 3 of rat POMC (courtesy of J. Eberwine) was subcloned into PGEM4 plasmid. For Northerns and RNase protections, padiolabelled cRNA probe was Iranseribed using ["P]CTP or ["3 P]UTP and T7 RNA polymerase ". For ISH. transcription wis identical except that ["S]UTP was used as a substrate.

In situ hybrilisution (ISH). Whole rat brains were frozen in an isopentane-liquid nitrogen slurry, hlocked and cut into $111 \mu \mathrm{m}$-thick sections on a Bright eryostat. Sections were then fixed in $4 \%$ phosphate-buffered lormaldehyde for $1 \mathrm{~h}$ and washed in phosphate. buffered saline. Hybridization was carried out essentially as de. scribed previously "2. Briefly, following standard pretreatment (proleinase $K$. acetic anhydride). $30 \mu \mathrm{l}$ of hybridization mix (75\% formamide) containing the POMC CRNA probe was applied per section. Following $12 \mathrm{~h}$ incubation at $61^{\circ} \mathrm{C}$, sections were washed in $2 \times S S C(3(1) \mathrm{mM}$ sndiun chloride, 31$) \mathrm{mM}$ sodium citrate), treatled with $R N_{\text {ase }} A(2(1) \mu g / \mathrm{ml})$ for $30 \mathrm{~min}$. then washed in decreasing concentrations of SSC buffer $(2 \times, 1 \times, 0.3 \times, 0.1 \times)$. Tissues were rapidly dehydrated and air dried, then dipped in Kodak NTB 2 nuclear emulsion. Autoriadiograms were developed (Kodak D19) after 5 weeks and examined with dark field microscopy.

Two negative and one positive controls were cerried out to ascertain that the whened signal was specific for POMC mRNA. For the negattive controls, sections were either pretreated with RNase 11 digest all single stranded RNA or were incubated with excess amounts of 'sense' strand POMC mRNA (i.e, identical to the POMC mRNA sequence) during the hybridization reaction. In both cases. no specific signal was detectable. As a positive control, the POMC riboprobe was incubated with hypothalamic brain sections. Confirming previous results ", many POMC-positive cells were observed in the arcuate nucleus (data not shown).

Northern analysis. Total RNA from different rat brain regions was extracted by the guanidium isothiocyanate (GITC)/ $\mathrm{LiCl}$ method ${ }^{6}$. After tissues were homogenized in GITC buffer (5.0 M GITC, $8 \%$ mercaptoethanol, $10 \mathrm{mM}$ EDTA, $50 \mathrm{mM}$ Tris pH 7.5), 6 vols. of 4.0 $\mathrm{M} \mathrm{LiCl}$ were added. and RNA was precipitated overnight at $4^{\circ} \mathrm{C}$. Poly $(A)^{+}$RNA was isolated by hybridization on oligo(dT)columns according to Sambrook et al. (1989). Different amounts of RNA (caudate $18 \mu \mathrm{g}$. NTS (total RNA) $28 \mu \mathrm{g}$, NTS (poly(A) ${ }^{+}$) $2 \mu \mathrm{g}$, IP 1 $\mu \mathrm{g}$. AP $10 \mu \mathrm{g}$. arcuate $33 \mu \mathrm{g})$ were run on a $1.5 \%$ agarose/ formaldehyde gel, then passively transferred to Nytran filters. Filters were hybridized with POMC cRNA probe at $60^{\circ} \mathrm{C}$ for $20 \mathrm{~h}$ (hybridization buffer: 5\% SDS, $400 \mathrm{mM} \mathrm{NaPO}, 1 \mathrm{mM}$ EDTA, 1\% BSA, 50)' formamide), washed $(0.1 \times$ SSC $(15 \mathrm{mM}$ sodium chloride, 1.5 mM sodium citrate), 0.1\% SDS, $1 \mathrm{mM}$ EDTA) 3 times at $70^{\circ} \mathrm{C}$ and exposed to X-ray film (Kodak X-Omat AR5) for different time periods with or without an intensifying screen (Dupont Cronex Lightning Plus).

RNase protection assay: Total RNA, poly $(A)^{+}$RNA or poly(A)RNA from different regions of rat brain (hypothalamus $35 \mu \mathrm{g}$. NTS $42 \mu \mathrm{g}$. $\operatorname{poly}(A)^{-}$NTS $6 \mu \mathrm{g}, \operatorname{poly}(A)^{+}$NTS $\left.1 \mu \mathrm{g}\right)$ were incubated in hybridization buffer (0.2 M PIPES, $2.0 \mathrm{M} \mathrm{NaCl}, 5.0 \mathrm{mM}$ EDTA, $50 \%$ (ormamide) at $55^{\circ} \mathrm{C}$ for $16 \mathrm{~h}$. Unprotected single stranded RNA was digested by RNase $\mathrm{A}(20 \mu \mathrm{g} / \mathrm{ml}$ in RNase buffer: $10 \mathrm{mM}$ Tris-HCl, $5.0 \mathrm{mM}$ EDTA, $0.2 \mathrm{M} \mathrm{NaCl}, 100 \mathrm{mM} \mathrm{LiCl}$ ) for $1 \mathrm{~h}$ at room temperature. RNase activity was terminated by Proteinase $K$ treatment $\left(100 \mu \mathrm{g} / \mathrm{ml}\right.$ in $1 \%$ SDS) at $37^{\circ} \mathrm{C}$ for $30 \mathrm{~min}$. Protected mRNA: cRNA hybrids were precipitated in ethanol, then fractionated by electrophoresis on $4 \%$ non-denaturing polyacrylamide gels in TBE buffer ( $90 \mathrm{mM}$ Tris-base, $90 \mathrm{mM}$ boric acid, $2 \mathrm{mM}$ EDTA). Gels were exposed to Kodak X-Omat AR5 X-ray film at $-80^{\circ} \mathrm{C}$ with $I$ intensifying screen.

\section{Pepride amalyses}

Immmumocytechemisty $(/ C C)$. Ruts pretreuted 48 h eurlier with 400 He of colchicine intriventricularly were perfused with $4 \%$ phosphute-buffered formaldehyde. Brains were renoved, incubuted in $15 \%$ sucpese solution overnight and then frozen in liquid nitrogen. 20) $\mu \mathrm{m}$-thick sections were cut and processed for ICC. The primary untibody, specific for the POMC lok frugment courteny of $\mathbf{E}$. Eipper), was used at a final dilution of $1: 10,0000$. Following $16 \mathrm{~h}$ incubation at $4^{\circ} \mathrm{C}$, secondary biotinylated antibody (gout unti-rabbit) was applied for $30 \mathrm{~min}$ at $37^{\circ} \mathrm{C}$. Detection followed using the avidin-anti-peroxidase complex (Vectastain) and $\mathrm{DAB} / \mathrm{H}_{2} \mathrm{O}_{2}$ for substrates. Control sections, in which excess $16 \mathrm{k}$ peptide was added to the incubation, showed no reaction product, confirming the specilicity of the immunorenctive signal detected.

$\beta E$ melioimmumosesse!n (RIA). Samples resuspended in RIA buffer (150) $\mathrm{mM}$ phosphate buffer, is NaCl, 0.1\% BSA) were incubated with primary antibody (Brenda) directed towards $\beta \mathrm{E}_{17-27}$, used at a final concentration of $1: 40,000$. Following incubation at $4^{\circ} \mathrm{C}$ for $1-2$ days with (12:1] $N$-acetyl- $\beta \mathrm{E}_{1-27}$ as the radiolabelled tracer, second antibody (goat anti-rabbit) was added and incubated for $3 \mathrm{~h}$ at room lemperillure. Pellets were spun down, the supernatant was removed and the amount of primary antibody-hound trace was measured in a gammi counter. $\beta$ E-ir concentrations were quantitated relative to a rat $\beta \mathrm{E}_{1}, 3$ standard curve. Under these conditions, Brenda reacted

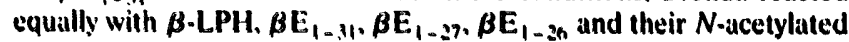
derivalives but had no affinity for any other peptides derived from any of the three opioid precursors!

\section{RESULTS}

ICC and ISH. ICC analysis revealed the presence of 16k POMC immunoreactivity in cell bodies in the NTS (Fig. 1A). As described previously ${ }^{16,17,3,}$, these cells 

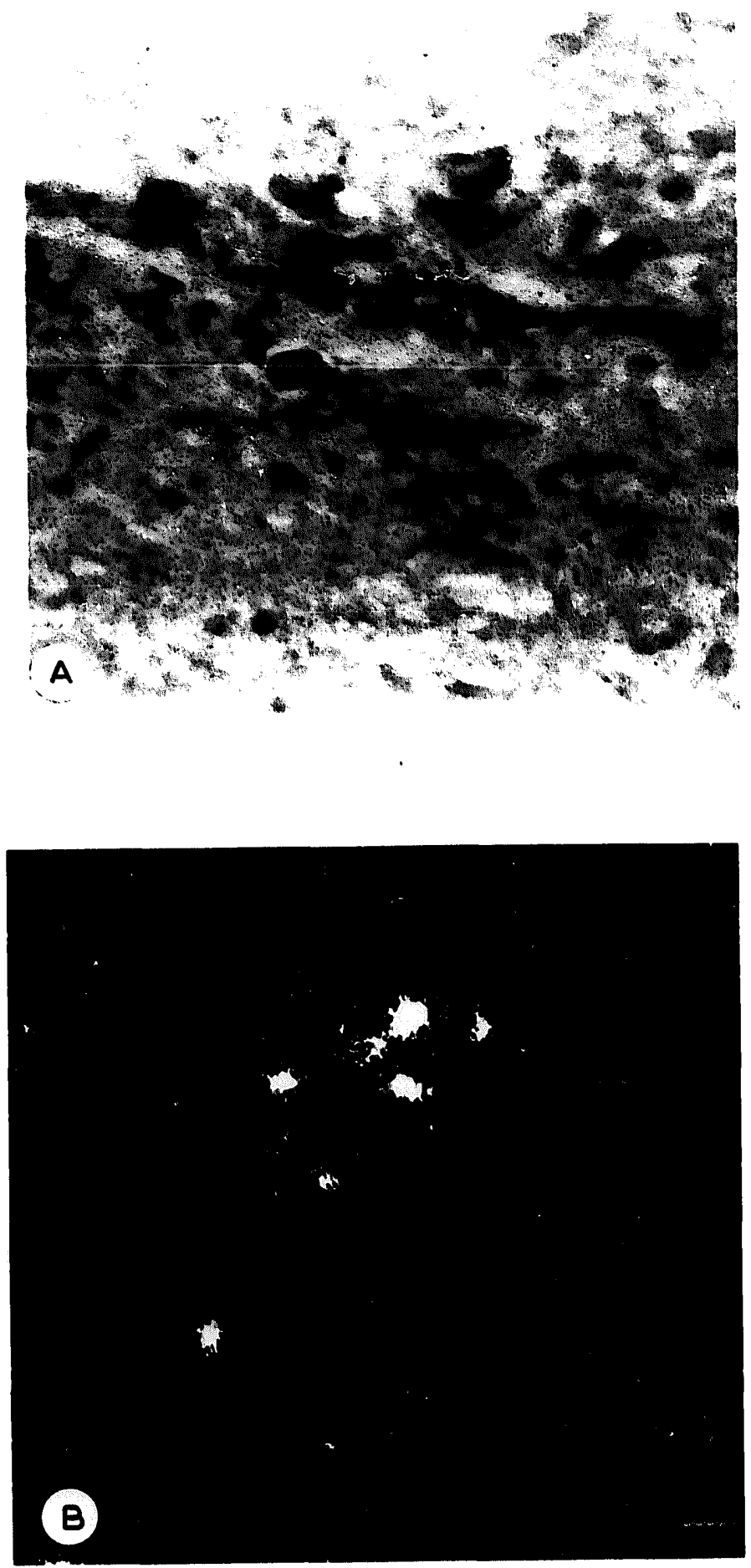

Fig. 1. Presence of POMC peptide-immunoreactivity (A) and POMC mRNA (B) in the caudal NTS. A: perfused rat brainstem blocks were cut in $20 \mu \mathrm{m}$-thick sections and processed for ICC. A primary antibody specific for the 16K POMC fragment was incubated with sections for $16 \mathrm{~h}$ at $40^{\circ} \mathrm{C}$. Biotinylated second antibody was applied and detected using avidin-anti-peroxidase complex and $D A B / \mathrm{H}_{2} \mathrm{O}_{2}$ as substrates $(\times 557)$. B: fresh frozen hrainstem blocks were cut into $10 \mu \mathrm{m}$-thick sections, post-fixed in formaldehyde and processed for in situ hybridization histochemistry. Following proteinase $K$ and acetic anhydride pretreatment, a ${ }^{35} \mathrm{~S}$-labelled POMC riboprobe was applied to sections in $30 \mu$ l of hybridization buffer. Sections were incubated for $12 \mathrm{~h}$ at $60^{\circ} \mathrm{C}$, then digested with RNase A. Sections were washed, dehydrated and air-dried before being dipped in Kodak NTB 2 nuclear emulsion. Autoradiograms were developed after 5 weeks and are shown here in darkfield $(\times 244)$. were localized in the caudal portion of the NTS in the vicinity of the commissural nucleus, extending as far back as the area postrema. ISH results indicated that POMC mRNA signal was also present in somata in the NTS (Fig. 1B). The distribution of POMC mRNA-containing cells closely paralleled that found by ICC, with cells restricted primarily to the caudal half of the NTS. While ICC and ISH analyses yielded very similar distribution of POMC-positive cells in the caudal medulla, our impression was that a fewer number of cells were detected with ISH compared with ICC. It is also noteworthy that 5 weeks exposure time was necessary to visualize the POMC mRNA signal in the NTS whereas POMC-positive cells in the arcuate nucleus were clearly detectable in 1 week by ISH (data not shown).

RNase protection assay. Hybridization of the 430 base POMC cRNA probe with RNA extracts from different POMC-containing tissues, followed by RNase digestion, produced a single protected band on polyacrylamide gels (Fig. 2). The size of this band was estimated to be roughly 400 bases, which corresponds to the length of the Exon 3 coding portion of the cRNA probe (i.e. the single stranded intronic portion of the probe was degraded by the RNase treatment). As expected, protected POMC signal was found in RNA extracteci from the hypothalamus (Fig. 2) as well as the

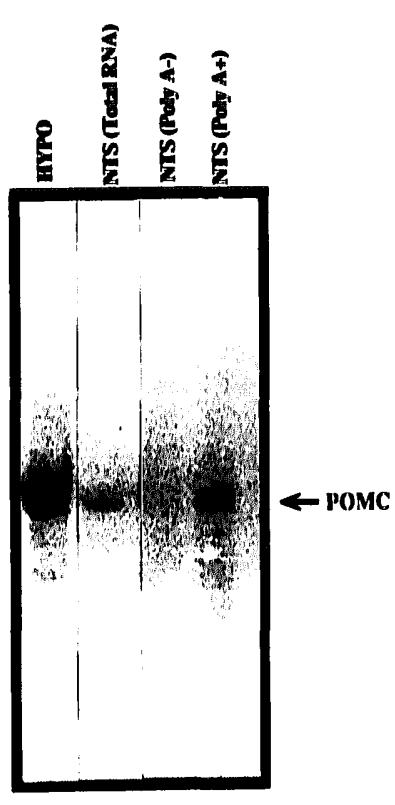

Fig. 2. Hypothalamus and NTS contain an identical nucleic acid sequence (approximately 395 bases) in the exon 3 region of POMC mRNA as determined by RNase protection. Total RNA. poly $(A)^{+}$ RNA or poly(A) - RNA from the hypothalmus or NTS was incubated with ${ }^{32}$ p-labelled POMC cRNA for $16 \mathrm{~h}$ at $55^{\circ} \mathrm{C}$. Single stranded RNA was digested by RNase $A$ followed by proteinase $K$ treatment. Protected mRNA:cRNA hybrids were precipitated in ethanol and fractionated by electrophoresis on a $4 \%$ non-denaturing polyacrylamide gel. The gel was exposed to X-ray film for $31 \mathrm{~h}$ at $-80^{\circ} \mathrm{C}$ with 1 intensifying screen. 


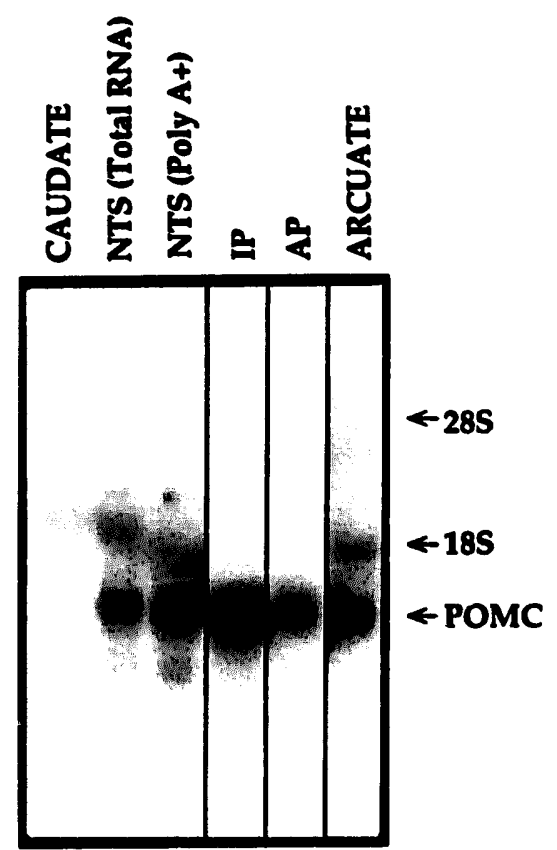

Fig. 3. Presence of POMC mRNA in the NTS. arcuate and pituitary (IP and AP) as determined by Northern analysis. Total RNA or moly(A) * purified RNA from different tissues were loaded on a I.Sf; agarese/formaldehyde gel, then passively transferred to $\mathrm{Ny}$ Iran fillers. The amount of RNA loaded was: cioudate $18 \mu \mathrm{g}$ : NTS (totill RNA) $28 \mu \mathrm{g}:$ NTS (Poly $\left.\mathrm{A}^{*}\right) 2 \mu \mathrm{g}:$ IP I $\mu \mathrm{g}$ : AP I() $\mu \mathrm{g}:$ arcuate $3.3 \mu \mathrm{g}$. Filters were hybridized with a "P-labelled POMC eRNA lor $20 \mathrm{~h}$ all hl $)^{\circ} \mathrm{C}$. Washed, and then exposed to $\mathrm{X}$-ray films for different lengths of time. Exposure conditions were: caudale. NTS (lotul RNA) NTS (poly(A)') bt h at $-X()^{\circ} \mathrm{C}^{\prime}$ with 1 intensifying sereen: IP \& $A P$ 1.75 h $1125^{\circ} C^{\circ}$ : arcuate o h at $25^{\circ} \mathrm{C}$.

\section{TABLLE I}

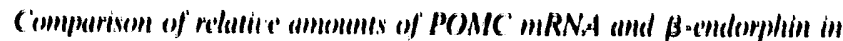
diflierent issures

Brain and pituitany regions were homogenized in GITC buffer. RNA was precipitated hy addition of $\& \mathrm{M} \mathrm{LiCl}$. Following centrifugation, RNA pellets were digested with proteinase $K$. extracted twice with phenol/chlorolorm and ethanol-precipitated. The protein-containing supernitant was processed on Sep-pak chromatography columns, dried down and resuspended in RIA buffer. POMC mRNA levels were determined by Northern and/or RNase protection assays and BE-ir wis defermined by RIA. Vulues, representing approxinatle amounts of mRNA or peptide per tissue. are expressed relative in anterior pituitary $(=1.0)$. Numbers in parentheses in $\beta$. Endorphin content column represent absolute concentrations (pmol/tissue) of $\beta$ E-ir.

\begin{tabular}{|c|c|c|c|}
\hline & $\begin{array}{l}P() M I C \\
M R N A 1\end{array}$ & $\begin{array}{l}\text { B.Endorphin } \\
\text { comem }\end{array}$ & $\begin{array}{l}\text { Rutio } \\
\text { mprtide } \\
\text { mRNA }\end{array}$ \\
\hline Anlerior pituitary & 1.11 & $1.0(2(1) \mathrm{pm})$ & 1.0 \\
\hline Intermediate pituitury & 5.11 & $5.1)(10 k 1) \mathrm{pm})$ & 1.0 \\
\hline Arcuilte nucleus & 0.25 & (1).025 (5 pm) & 0.1 \\
\hline $\begin{array}{l}\text { Whole arcuitte system } \\
\text { (somatia + nerve } \\
\text { (erminal regions) }\end{array}$ & & & \\
\hline NTS & 0,025 & $\begin{array}{l}0.25(50 \mathrm{pm}) \\
0.0(1) 25(10.5 \mathrm{pm})\end{array}$ & $\begin{array}{l}1.0 \\
0.1\end{array}$ \\
\hline $\begin{array}{l}\text { Whole NTS system } \\
\text { (somitil + nence } \\
\text { terminil regions) }\end{array}$ & - & $0.01(2 \mathrm{pm})$ & 0.4 \\
\hline
\end{tabular}

anterior (AP) and intermediate pituitary (IP) (data not shown). A similar size band was observed in total or poly(A) ${ }^{+}$RNA from the NTS but not in the poly(A)RNA fraction (Fig. 2).

Northern analysis. Northern analysis confirmed the RNase protection data, demonstrating the presence of POMC mRNA in the NTS, in addition to its expected presence in both lobes of the pituitary gland and the arcuate nucleus; in contrast, no POMC signal was detected in total RNA from the caudate nucleus (Fig. 3). The length of time necessary for visualizing the POMC signal varied greatly between the different tissues and brain regions. Intense IP and AP signals were observed after less than $2 \mathrm{~h}$ exposure at room temperature; on the other hand, the NTS lanes were exposed for $94 \mathrm{~h}$ with an intensifying screen (at $-80^{\circ} \mathrm{C}$ ) before a quantifiable band was obtained. In all of the POMCcontaining tissues, the size of the mRNA corresponded to roughly $1.2 \mathrm{~kb}$. A larger molecular weight band (approx. $6 \mathrm{~kb}$ ) can be faintly observed in the IP lane and most likely represents the full-length primary POMC transcript. Interestingly, a smaller POMC-positive band (approx. 800-900 bases in size) was observed in the NTS lanes (Fig. 3).

Peptide measures. Total amounts of $\beta E$-ir were determined in different tissues and compared to levels of POMC mRNA in these tissues. In general, there was a strong correlation between the relative amounts of POMC mRNA and $\beta$ E-ir peptides found in a tissue, with intermediate pituitary containing the highest concentrations of both peptide and message, and the NTS containing the lowest. Peptide concentrations, expressed relative to AP levels, were calculated as a ratio of POMC mRNA concentrations (also expressed relative to AP levels) to provide a gross estimate of the amount of peptide produced per mRNA molecule in different tissues. Peptide/mRNA ratios in the anterior and intermediate pituitary lobes were more or less equal; in contrast, the relative amounts of peptide to mRNA in the arcuate nucleus or NTS were roughly $1 / 10$ of that found in either lobe of the pituitary (Table I). However, since the bulk of peptides synthesized in a neuron are transported axonally away from the cell body (in contrast to pituitary cells), an estimate of the total amount of $\beta E$-ir in rostral and caudal nerve terminal projection regions was made for both the arcuate and NTS cell goups, respectively. Including $\beta$ E-ir from all brain regions rostral to the midbrain/medulla increased peptide/mRNA ratios approximately 10-fold in the arcuate POMC system to levels found in the IP or AP. For the whole NTS system, even when the total $\beta E$-ir in the medulla and spinal cord was included, the peptide/mRNA ratio 
remained less than half that observed in other POMC systems (Table I).

\section{DISCUSSION}

The results of this study provide strong evidence that there are POMC-producing cells in the NTS. The anatomical studies demonstrated that POMC mRNA and POMC peptide product (i.e. 16k POMC peptide) are both found in cells in the caudal medulla. Northern and solution hybridization analyses indicated that the POMC mRNA found in the NTS appears to be homologous to that found in the arcuate nucleus or pituitary gland. It has been shown previously that there are a number of cases, both in the brain and periphery, where the presence of POMC mRNA signal is not necessarily associated with POMC peptide biosynthesis. For example, POMC mRNA has been found in various brain regions (e.g. amygdala, midbrain, cortex) ${ }^{10,30}$ where there is no evidence of POMC-containing cell bodies, as determined by ICC. Similarly, in the testes and other reproductive organs, only minute quantities of $\beta E$-ir are found ${ }^{24}$ even though significant amounts of POMC mRNA are present ${ }^{8,9,31}$. In these cases, though, the apparent size of the POMC message is roughly 200 bases shorter than that observed in the pituitary or arcuate. It has been suggested that the shorter POMC mRNA may not be efficiently translated into protein ". Furthermore, since the 5' end (including exons 1 and 2 and intron 1) is missing from the truncated POMC message, even if a protein were translated, the absence of a signal-like sequence makes it unlikely that this protein would be processed and stored properly ${ }^{21}$. In contrast to the examples just mentioned, there are several reasons to believe that POMC mRNA in the NTS is translated into protein products. First, the vast majority of POMC mRNA in the NTS was approximately the same size as that found in the pituitary or arcuate. Second, the riboprobe containing the first 350 bases of exon 3 hybridized and was protected in NTS, arcuate and pituitary samples, suggesting that, at least in this coding region, these tissues have identical POMC mRNA sequences. Finally, POMC mRNA and 16k peptide immunoreactivity were observed in the same region of the NTS, presumably in the same cells. While co-localization studies of POMC mRNA and peptide would have provided conclusive evidence, it is difficult to imagine why (or how) cells containing POMC message without POMC peptides would reside adjacent to other cells which contain POMC peptides but no POMC mRNA. Taken together, the present data lead us to suggest that, in addition to the pituitary gland and arcuate nucleus, there are POMC-synthesizing cells in the NTS. It should be noted that a lower molecular weight species (800-900 bases) of POMC mRNA was also observed in the NTS although it was much less abundant than the $1.2 \mathrm{~kb}$ size message. It would be interesting to determine the similarities between the truncated POMC mRNA in the NTS and the shortened species found in peripheral tissues, in terms of sequence homology, protein expression and regulation.

While ICC and in situ techniques demonstrated the presence of POMC peptide and mRNA in some NTS cells, there appeared to be some discrepancy between the results of these two methods. Although cell counts were not performed, our impression was that more cells were found to contain 16k POMC peptide immunoreactivity compared to the number expressing POMC mRNA signal. Even after 5 weeks exposure, relatively few cells showed POMC mRNA expression One explanation for this could relate to the low level of POMC expression in these cells and the difficulty in detecting such low abundance messages. An alternative explanation for the discrepancy between the ICC and in situ data is that there was an induction in the number of cells expressing the 16k peptide because of the use of colchicine in the ICC studies. Colchicine is routinely used in ICC to block axonal transport of substances, thereby increasing the signal detectable in the cell body. However, it has been shown that colchicine induces neurons in some brain structures to express neuropeptide mRNA's which are not normally expressed ${ }^{7.11}$. It is possible that in the present studies, colchicine was responsible for the greater number of POMC cells which contain 16k peptide compared to those expressing POMC mRNA. If the in situ data are in fact representative of the normal basal status of the animal, they would suggest that the POMC cell group in the NTS is an extremely small one and could account for past difficulties in detecting POMC message in this brain region. In this regard, it should be noted that in each of the techniques employed in these studies, the detection of POMC mRNA signal in the NTS approached the limits of detection and at times produced variable results.

When the relative amounts of POMC mRNA and $\beta E$-ir peptides were compared in different tissues and brain regions, we found that the ratio of POMC peptide/mRNA in pituitary was approximately 10-fold greater than that found in brain tissue. This would seem to imply that pituitary cells produce much more peptide product per POMC mRNA molecule than neuronal cells. The reason for this tissue-specific difference is probably due, at least in part, to the fact that in endocrine cells, peptide biosynthesis and storage 
occur in close proximity to one another whereas in neurons, peptide products are often transported far away from the site of biosynthesis for storage in nerve terminals. Thus, if peptide levels are measured only at the site of biosynthesis (i.e. in cell body regions), as they were in the brain, it is probable that peptide/mRNA ratios are greatly underestimated. If the total amount of $\beta E$-ir found in the rostral portion of the brain is estimated and assumes that it is all derived from the arcuate cell group, as results from lesion ${ }^{19}$ or knife-cut studies ${ }^{15,2 \mathrm{~K}}$ suggest, then the total amount of $\beta \mathrm{E}$-ir produced by arcuate POMC cells increases approximately 10 -fold and the POMC peptide/mRNA ratio increases concurrently to roughly the same levels seen in the pituitary. Analogous calculations are more difficult to justify in the caudal portion of the brain since $\beta \mathrm{E}$-ir in the medulla, and possibly spinal cord, is derived from both the NTS and arcuate cell groups ${ }^{15,2 \mathrm{~K}}$. However, even if one assumes that all of the $\beta E$-ir found in the brainstem and spinal cord is produced solely by POMC cells in the NTS (with no contribution from arcuate neurons), the POMC peptide/mRNA ratio for the NTS cell group still remains less than half that seen in the arcuate or pituitary. While the precise reasons for this difference in peptide/mRNA ratios between arcuate and NTS neurons are not eurrently known, they may involve differences in translational efficiency, POMC processing. peptide storage or basal $\beta E$ release.

The demonstration that POMC mRNA is found in the NTS, in the same areas where POMC peptides are localized, provides the strongest evidence to date that $\beta E$ is synthesized in this brain region. The presence of $\beta E$-producing neurons in the NTS is consistent with a physiological role for $\beta E$-ir peptides, as well as other POMC products, in this brain region. For example, intracisternal injections of full length $\beta E_{|-3|}$ or the C-terminal shortened $\beta \mathrm{E}_{1,27}$ reduce mean arterial blood pressure ${ }^{12}$ increase plasma concentrations of dopamine, norepinephrine and epinephrine ${ }^{34.35}$ and depress respiratory function ${ }^{25}$. These data suggest a putative involvement of $\beta E$-related peptides in the regulation of autonomic function, including cardiovasscular, respiratory, and sympathetic nervous system responses. Other data, showing that electrical stimulation in the NTS elicits opioid-mediated analgesia ${ }^{21}$ indicate that $\beta E$ might be part of an endogenous antinociceptive pathway in the brainstem. The present data, providing solid evidence of $\beta \mathrm{E}$-producing cells in the NTS, places this opioid peptide at a brain site where autonomic and antinociceptive information converge. However, the presise role of $\beta E$ and other POMC peptides in the NTS awaits further study.
Acknowledgements. This work was supported in part by a NIDA Grant DA 02265 (H.A.) and a Medical Research Council of Canada Postdoctoral Fellowship (D.B.). We thank Dr. J. Eherwine for providing the rat POMC cDNA and Sharon Burke for technical assistance.

\section{REFERENCES}

1 Akil, H., Watson, S.J., Barchas, J.D. and Li, C.H., Beta-endorphin immunoreactivity in rat and human blood: radioimmunoassay, comparative levels, and phsyiological alterations, Life Sci.. 24 (1979) 1659-1666.

2 Akil, H., Watson, S.J., Young, E., Lewis, M.E., Khachaturian, $H$. and Walker, J.M., Endogenous opioids: biology and function. In W.M. Cowan (Ed.), Anmual Retiew of Neuroscience, Vol. 7, Annual Review Inc., Palo Alto, CA, 1984, pp. 223-255.

3 Bloch, B., Bugnon, C., Fellman, D. and Lenys, D., Immunocytochemical evidence that the same neurons in the human infundibular nucleus are stained with anti-endorphins and antisera of other related peptides, Neurosci. Lett., 10 (1978) 147-152.

4 Bloom, F., Battenberg, E., Rossier, J., Ling, N. and Guillemin, R., Neurons containing beta-endorphin in rat brain exist separately from those containing enkephalin: immunocytochemical studies, Proc. Natl. Acad. Sci. USA, 75 (1978) 1591-1595.

5 Bronstein. D.M., Schafer, M.K.H., Trujillo, K.A., Watson, S.J. and Akil, H., Pro-opiomelanocortin (POMC) mRNA in the nucleus tractus solitarius and other extrahypothalamic brain regions, Soc. Neurosci. Abstr. 16 (1990) 1026.

6 Cathala, G., Savouret, J.T., Mendez, B., West, B.L., Karin, M., Martial, J.A. and Bexter, J.D., A method for the isolation of intact, translationally active ribonucleic acid, DNA, 2 (1983) 329-335.

7 Ceceutelli. S., Cortes, R, und Hokfelt, T., Effect of reserpine and colchicine on neuropeptide mRNA levels in the rut hypothalamic paraventricular nucleus, Mol, Brwin Res., 9 (1991) $57=69$.

R Chen, C.L.C., Chung, C.C., Krieger, D.T, und Bardin, C.W., Expression und repulation of proroplomelanocortindlike gene in the ovary and placenta: Comparison with the lestis, Bindocrinol. (opy, IIK (1986) 2362-2369,

9 Chen, C.L.C., Mather, J,P. Morris, P.L. and Bardin, W.C.. Expression of pro-opiomelanocortin-like gene in the testis and epididymis, Proc. Natl. Acudl. Sci, USA, 81 (1984) 5672-5675.

10) Civelli, O., Birnberg, N. and Herbert, E., Detection and quantitation of pro-opiomelanocortin mRNA in pituitary and brain tissues from different species, J. Biol. Chem., 257 (1982) 6783-6787.

II Gee, C., Chen, C.-L.C., Roberts, J., Thompson, R. and Watson, S.I. Identification of pro-opiomelanocortin neurons in rat hy. pothalamus by in situ cDNA-mRNA hybridization. Nenture, 30\% (1983) 374-376.

12 Hirsch, M.D., Millingoon, W.R., Mckenzie, J.E. and Mueller, G.P. $\beta$-Endorphin(1-27) is a potent endogenous hypotensive igent, Sex. Neurosci. Abstr. 14 (1988) 465.

13 Holiday. J., Endegsenous Opioids and Their Receptors, The Upjohn Co, Kilamazoo, 1985.

I4 Jacobowita. D.M. and O'Donohos, T.L., $\alpha$-Melanocyte stimulating hormone: immunohistochemical identification and mapping in neurons of ratt brain. Proc. Netl. Acad. Sci. USA, 75 (1978) 6300)-6304.

15 Joseph, S.A. and Michael, G.J., Efferent ACTH-IR opiocortin projections from nucleus tractus solitarius: a hypothalamic deafferentation study, Pepticles, 9 (1988) 193-201.

16 Joseph, S.A., Pilcher, W.H, and Bennet-Clarke, C., Immunocytochemical localization of ACTH perikarya in nucleus tractus solitarius: evidence for a second opiocortin neuronal system. Neurosci. Lett, 38 (1983) 221-225.

17 Khachaturian, H., Lewis, M.E., Tsou, K. and Watson, S.J., $\beta$-Endorphin. $\alpha$-MSH, ACTH, and related peptides. In A. Björklund and T. Hökfelt (Eds.), Handbook of Chemical Neuroanatomy, Vol. 1. GABA and Neuropeptides in the CNS. Part I, Elsevier, Amsterdam, 1985, pp. 216-272. 
18 Kiyama, H. and Emson, P.C., Colchicine-induced expression of proneurotensin mRNA in rat striatum and hypothalamus, Mol. Brain Res., 9 (1991) 353-358.

19 Krieger, D.T., Liotta, A., Nicholsen, G. and Kizer, J., Brain ACTH and endorphin reduced in rats with monosodium glutamate-induced arcuate nuclear lesions, Nature 278 (1979) 562-563.

20 Lacaze-Masmonteil, T., de Keyzer, Y., Luton, J.-P., Kahn, A. and Bertagna, $X$., Characterization of pro-opiomelanocortin transcripts in human nonpituitary tissues, Proc. Natl. Acad. Sci. USA, 84 (1987) 7261-7265.

21 Lewis, J.W., Baldrighi, G. and Akil, H., A possible interface between autonomic function and pain control: opioid analgesia and the nucleus tractus solitarius, Brain Res., 424 (1987) 65-70.

22 Liotta, A.S., Advis, J.P., Krause, J.E., McKelvy, J.F. and Krieger, D.T., Demonstration of in vivo synthesis of pro-opiomelanocortin-, $\beta$-endorphin, and $\alpha$-melanotropin-like species in the adult rat brain. J. Neurosci., 4 (1984) 956-965.

23 Liotta, A.S., Loudes, C., McKelvy, J.F. and Krieger, D.T., Biosynthesis of precursor corticotropin/endorphin-, corticotropin-, $\alpha$ melanotropin-, $\beta$-lipotropin-, and $\beta$-endorphin-like material by cultured rat hypothalamic neurons, Proc. Natl. Acad. Sci. USA, 77 (1980) 1880-1884.

24 Margioris, A.N., Liotta, A.S., Vaudry, H.. Bardin, C.W. and Krieger. D.T., Characterization of pro-opiomelanocortin-related peptides in rat testes, Endocrinology, 113 (1983) 663-671.

25 Moss, I.R. and Friedman, E., B-endorphin - effects on respiratory regulation, Life Sci., 23 (1978) 1271-1276.

26 Nilaver, G., Zimmerman, E.A., Defendini, R., Liotta, A., Krieger, D.A. and Brownstein, M. Adrenocorticotropin and $\beta$-lipotropin in hypothalamus, J. Cell. Biol., 81 (1979) 50-58.

27 Palkovits, M. and Eskay, R.L., Distribution and possible origin of $\beta$-endorphin and ACTH in discrete brainstem nuclei of rats, Neuropeptides, 9 (1987) 123-137.

28 Palkovits, M., Mezey, E. and Eskay, R.L., Pro-opiomelanocortinderived peptides (ACTH/ $\beta$-endorphin/ $\alpha$-MSH) in brainstem haroreceptor areas of the rat. Brain Res., 436 (1987) 323-328.
29 Pelletier, G. and LeClerc, R., Immunohistochemical localization of adrenocorticotropin in one rat brain. Endocrinology. 104 (1979) $1426-1433$

30 Pintar, J.E., Schacter, B.S., Herman, A.B., Durgerian, S. and Krieger, D.T., Characterization and localization of pro-upiomelanocortin messenger RNA in the adult rat testis. Science, 225 (1984) 632-634.

31 Sambrook, J., Fritsch, E.F. and Maniatis, T., Molecular Cloning: a Laboratory Manual, Cold Spring Harbor Laboratory Press, Cold Spring Harbor, 1989.

32 Schafer, M.K.-H., Day, R., Ortega, M.R., Akil, H. and Watson, S.J., Proenkephalin messenger RNA is expressed both in the rat anterior and posterior pituitary, Neuroendocrinology, 51 (1990) 444-448.

33 Schwartzberg, D.G. and Nakane, P.K., ACTH-related peptide containing neurons within the medulla oblongata of the rat, Brain Res., 276 (1983) 351-356.

34 Van Loon, G.R., Appel, N.M. and Ho, D., $\beta$-endorphin-induced increases in plasma epinephrine, norepinephrine and dopamine in rats: inhibition of adrenomedullary response by intracisternal somatostatin, Brain Res., 212 (1981) 207-214.

35 Van Loon, G.R., Appel, N.M. and Ho, D., $\beta$-endorphin-induced stimulation of central sympathetic outflow: $\beta$-endorphin increases plasma concentrations of epinephrine, norepinephrine and dopamine in rats, Endocrinology, 109 (1981) 46-53.

36 Watson, S.J., Akil, H., Richard, C.W. and Barchas, J.D., Evidence for two separate opiate peptide neuronal systems and the coexistence of beta-lipotropin, beta-endorphin and ACTH immunoreactivities in the same hypothalamic neurons. Nature, 275 (1978) 226-228.

37 Watson, S.J., Barchas, J.D. and Li, C.H., Beta-lipotropin: localization in cells and axons in rat brain by immunocytochemistry. Proc. Natl. Acad. Sci. USA, 74 (1977) 5155-5158.

38 Watson, S.J., Richard, C.W. and Barchas, J.D., Adrenocorticotropin in rat brain: immunocytochemical localization in the cells and axons, Science, 200 (1978) 1180-1182. 